\title{
دراسة تحليلية و تجريبية للمشغولات النسجية وأثرها في تنمية المهارات والتعبيرات الفنية للطفل لاتلفيل
}

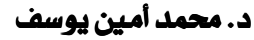 \\ وكيل الكلية لشئون خدمة المجتمع وتنمية البيئية

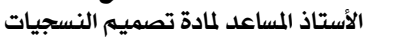 \\ كلية التربية النوعية - جامعة القاهرة / فرعيات الفيوم
}

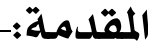

\section{( علموا أولادكم، فإنهم خلقوا لزمان غير زمانكم)}

هذة كلمات حكيمة للإمام على كرم الله وجهه ، لقد أوجب التعليم بفعل أمر ، ولكن إنهان

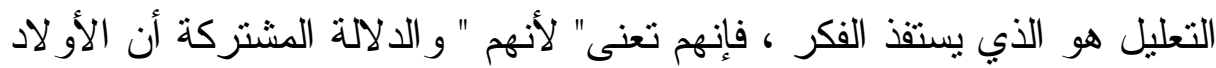

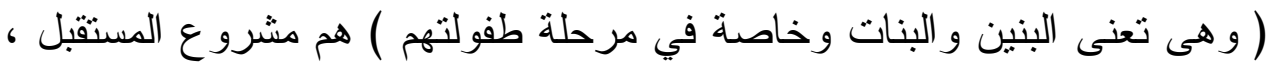

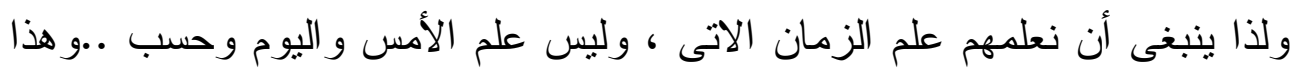

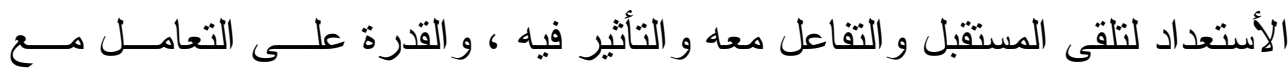
الحاضر و اختبارة بالمهار ات و التجارب المستمرة .

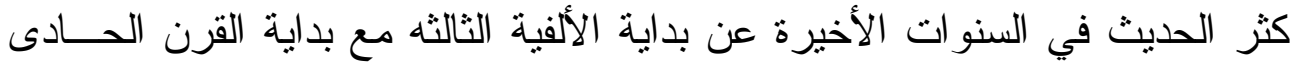

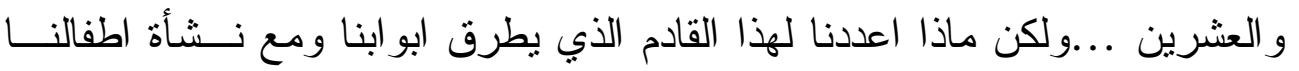

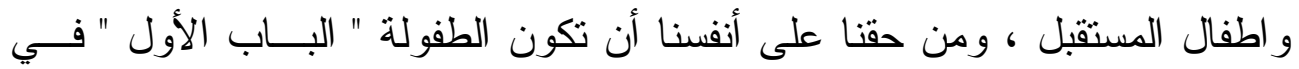

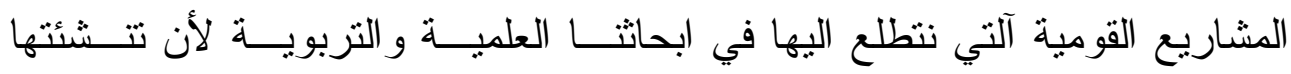

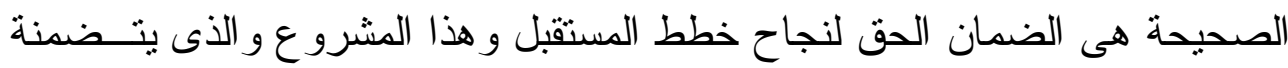

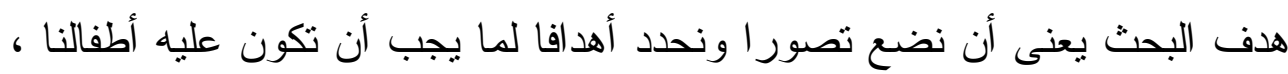
من ثقافة و علم ومهارة مستقبلا ، و هذا بدورة بساعد على تحديد الوسائل التعليميــة

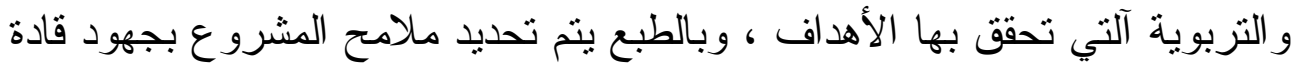

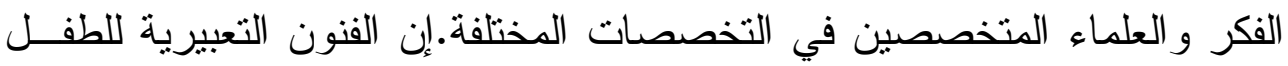


(') حجر الزاوية في توجهه النفسى والفكرى و العلمى و الأجتماعى ، وهذه

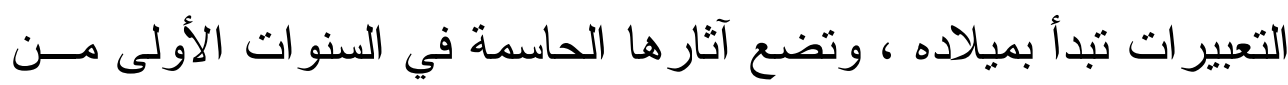

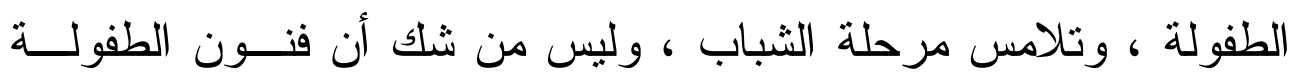

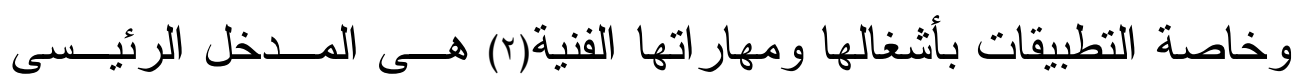
لموضوع البحث ، ومنها فنون النسجيات(ب) بهن

( ) التعبير الفنى للطفل -من منهج تدريس التربية الفنية للفرقة الدراسية الثانية بقسم رياض الأطفال بكلية التربية النوعية .المهارات الفنية مـادة

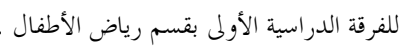
r) الأشغال الفنية -مادة من منهاج الفرق الدراسية الأولى والثانية والثالثة بقسم التربية الفنية بكلية التربية النوعية .

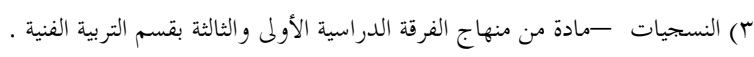

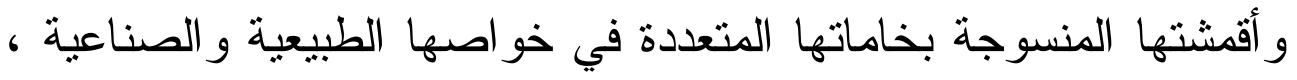
و المشبعة و القادرة على مخاطبة الطفل عاطفة وفكر ا وتطبيقاهوتقويمهــا

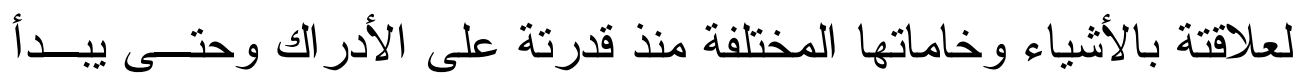

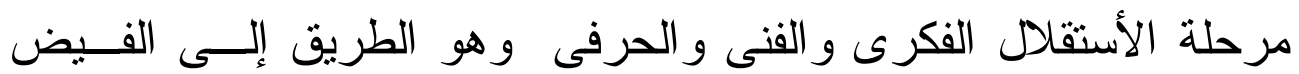
الإبداعى .

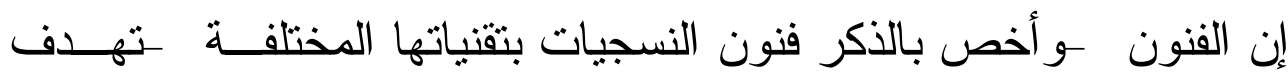
بوجه عام ولأطفال بوجه خاص ، إلى رياضة الملكات البشرية بحيـــث

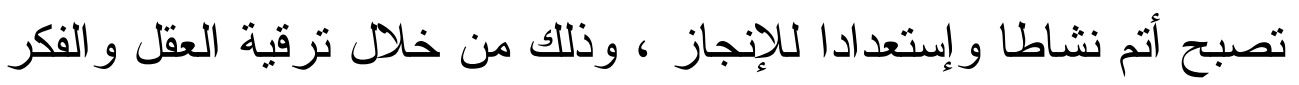

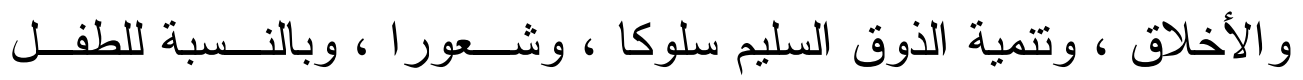
المصري في المر احل العمرية آلتي نتعامل معها سيكون الإمداد بالمعرفة

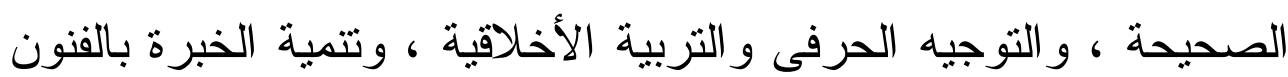


التطبيقية و أخص بذكر ها في النسيج ومنتجاتة المنسوجة و المساعدة علـىى التكيف مع الجماعة كما يحدث في مجال الكليم و السجاد اليدوى ........

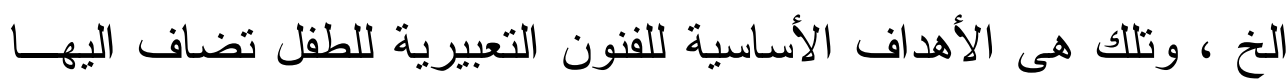
الأهداف التعليمية والتدريب على التعبير الفنى بفكرة واحدة وبأكثر مــن التهن طريقة وهى الاشغال الفنية للنسجيات وطرق تتفيذها وتطبيقها يدويا ، إما

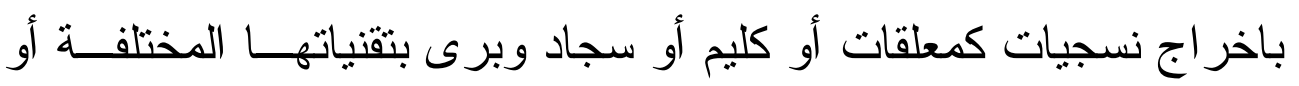
منسوجات ( أقششة ) بخامات و ألوان مختلفة كأقششة الخيام أو بتهــصيل

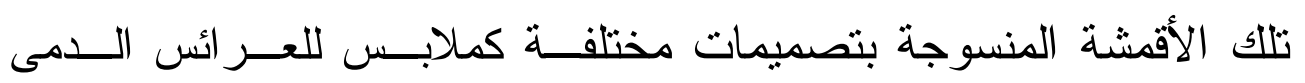

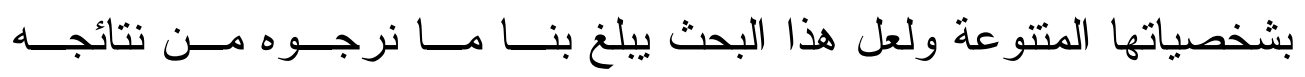
ولضرورة الدر اسة التحليلية والتجريبية لهذا البحث ، فقد ظهرت الحاجة

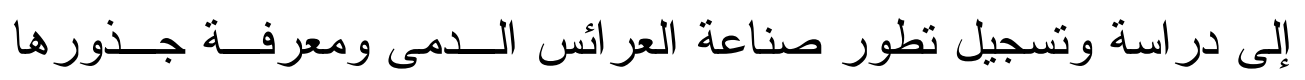
التاريخية لإدر الك مدى التو اصل التقافي و الفنى و الحرفى بتحليل الأساليب

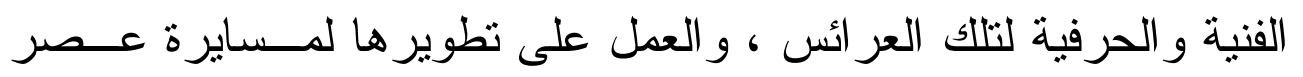

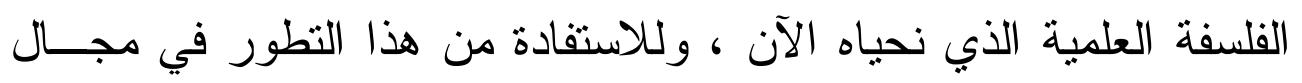
الأشغال الفنية وارتباطها بالأشغال النسجية. فقد ارتبطت عر ائس الدمى بخيال الإنسان منذ تاريخه الحضاري ، فهـى نتائج خيال الإنسان الأول ، وهى المحرك المثير الذي نمى هذا الخيــال

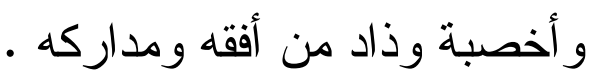
وفن العر ائس ليس غريبا على مصر و لا جديدا أو مستحدثا بها ، بــلـ إن ومان الحضارة المصرية تعتبر من أقدم الحضار ات التي ظهرت فيها ونها العر ائس 
بشكل أو آخر ، وقد كانت محل عناية المصريين القــدماء ، وازدهــرت ايضـا بين الثعب المصري في القرون الوسطى ( العصر الفاطمى ومهـــا

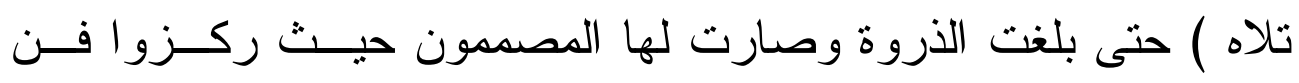

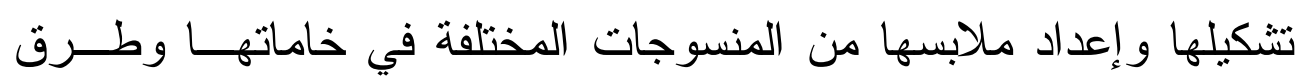

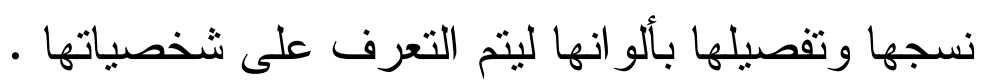
وقد تعددت وظائف العر ائس في فتر ات مختلفة مــن تــاريخ الحـــارة

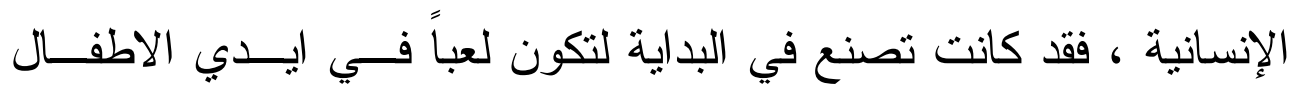
الصغار ليدركون بو اسطتها أغلب تجارب الحياة التي تتاسب أعمار هم ـ الإنه

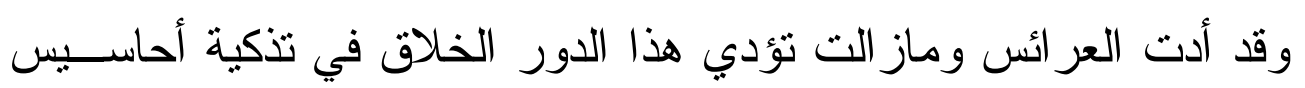

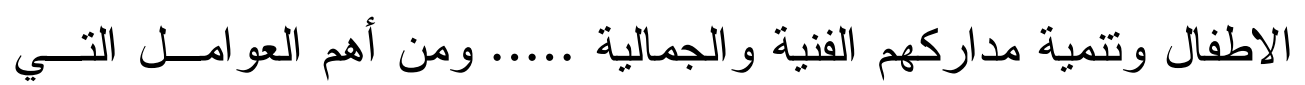
ساعدت على الاهتمام بفن العر ائس في العصر الحديث اكتثاف الأهميــة

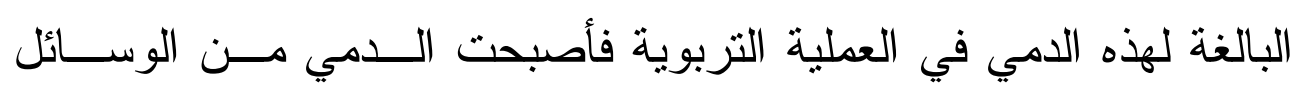
التزبوية في المدرسة وخاصة تللك التي يصنعها الطلاب ، أو التي تقدمها فرق تطوف بالمدارس وتقدم الأدب و العلم وسائر فروع المعرفـــة فــي

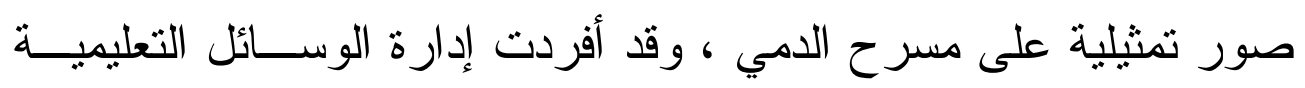

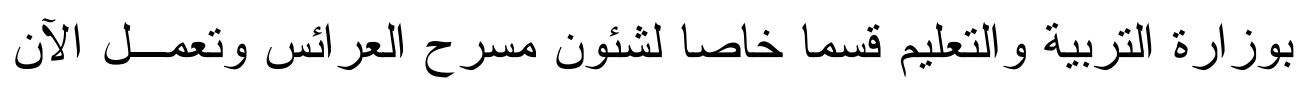

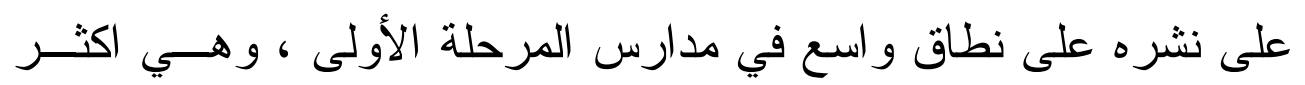

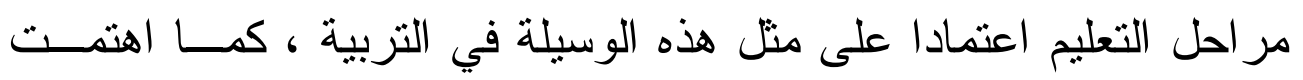

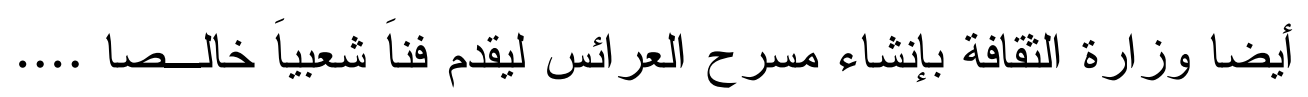


وترجع الأهمية التربوية لتلك العر ائس إلى أن قوة المخيلة عند الاطفــال

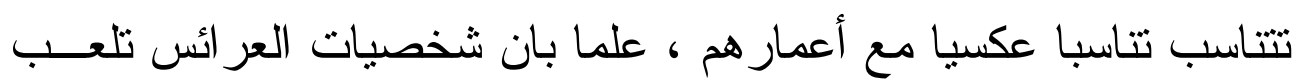

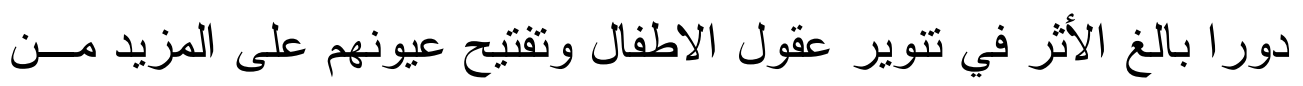
تجارب الحياة وترغيههم في حب الفن وتتمية حاسة تذوقهم الفني •

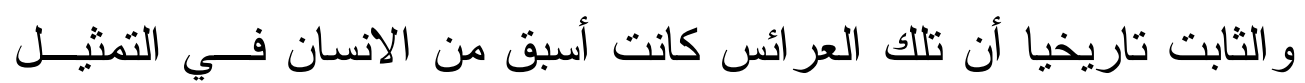

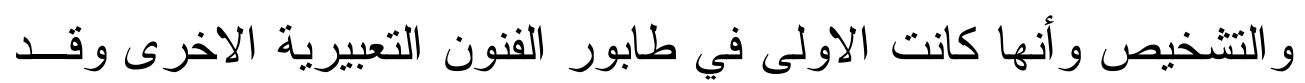
عرفها المصريون القدماء و الفينيقيون و الآشوريين و الهنود و الــصينيون

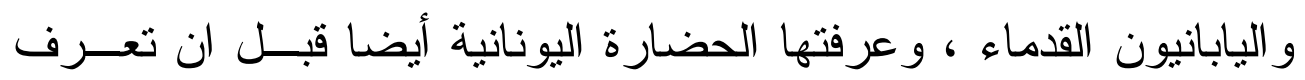

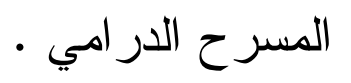

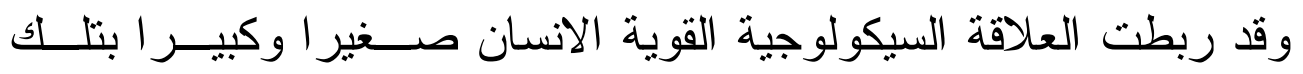

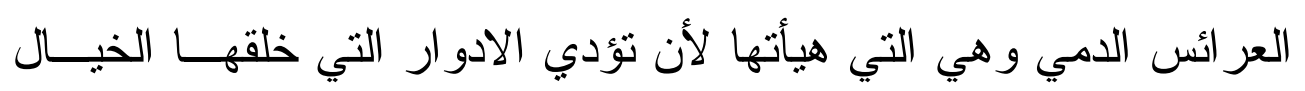
الانساني وضمنها الاساطير و القصص الخيالية التي تحفل بها حضار ات

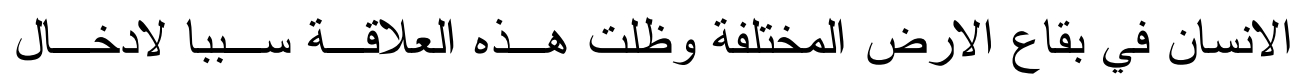
السرور الى قلب كل إنسان يشاهد العر ائس التي أبلغت في التأثير علــى لأهى نفوس الناس من الممثلين و الآدميين ، ذلك لأن حالة الانبهار التي تستحوذ التهن

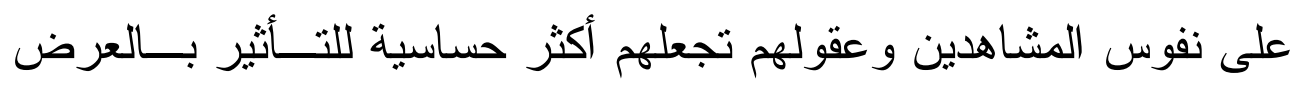
و هدفه ، ولذلك فلم يكن من الغريب أن تتولى العر ائس في فجر تاريخهــا

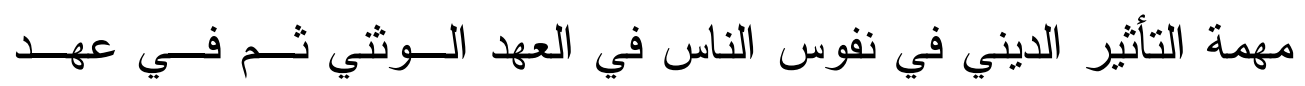

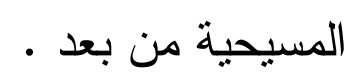




\section{مشكالة البحث:*}

تعني مشكلة البحث بدر اسة تنمية التعبير ات الفنية للاطفال مــن خــلال

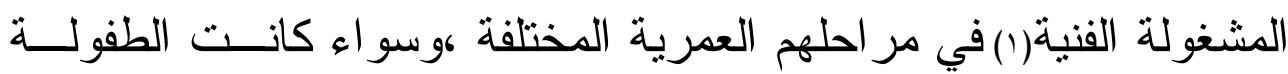
تمتد من السنة الاولى الى الخامسة عشر فالمقصود بتلك التعبير ات الفنية

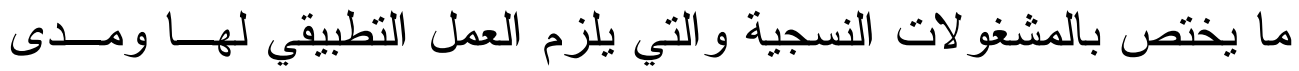
إمكانية و تصنيع و إخر اج تلك المشغو لات بأيدي الاطفال مع بداية الـسنة

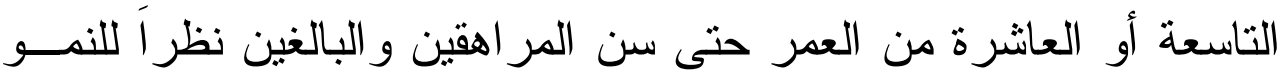
الجسمي و العقلي و الحركي و الوجداني و الاجتماعي للطفل وكيف يتم ذلك

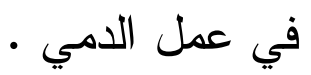

()المشغولة الفنية :- هي القطعه الصغيرة التي بستطيع ان يصنعها الطفل بعيد عن الملل وبالأستفادة مـن مهار اتـهـ الفنية .

\section{*هدف البحث:}

1و11 : محاولة تشكيل وتتفيذ الدمية بطابعها الفني لتغذية الاطفال بالاعـــداد العلمي و الفني التطبيقي لتنمية مهار اتهم و إخر اج و إنتاج مبتكر بمستويات

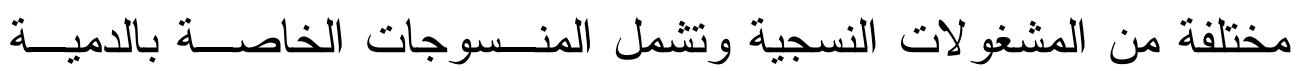
و المعلقات و السجاد و الكليم . 
أ-الاعداد العلمي لتتمية مستوى الوعي و الادر الك المعرفي للطفل . ب-الاعداد العلمي لنتمية مستوى الحركة و المهارة اليدوية .

\section{* أهمبة البـن}

بسهم هذا البحث في الارتقاء بتربية الطفولة في البيئة المصرية ، ليكونو اليكا

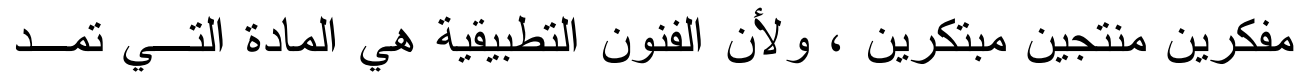
الطفل بالخبر ات التي يستطيع أن ينمو من خلالها في اتجاهــات عمليــة فئة مرغوب فيها اجتماعيا كحرفة مهنية ....ويمكن تحديد مسسيرة العمليــة

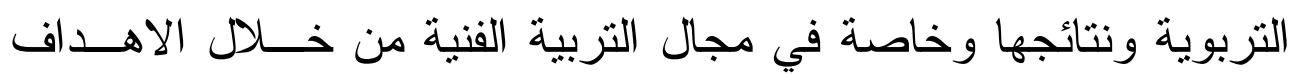
التالية : ا-مساعدة الاطفال على العناية بمستو اهم العلمي و الفني •

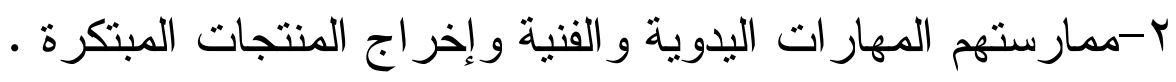

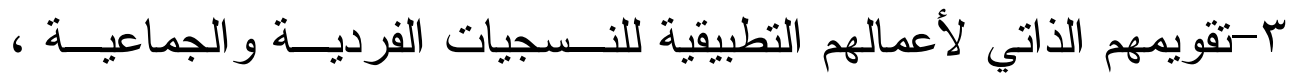

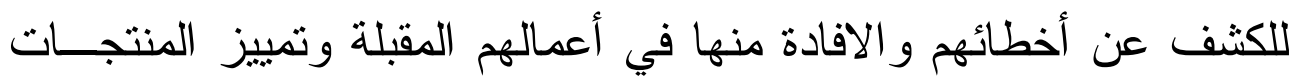
الجيدة في أدائها الموضحة لتعبير اتهم الفنية .

ع-تتمية ثقة الاطفال في ذاتهم من خلال إنجاز هم لمنتجاتهم الممتازة . ه-أهمية التطبيقات التزبوية إذ تتمي إدر الك الاطفال لنوعية الخامات التي دن التي تستخدم في الإنتاج وتتنمل الخو اص الطبيعية كاللون و الملمس و المتانــة

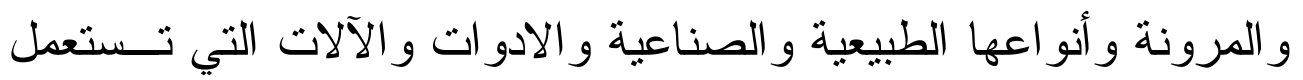


في تشغيلها في الانشطة التخطيطية المنتظمة .

\section{*فروض البـهن}

ا-يمكن انتاج نسيج يدوي في شكل اقمشة ومنسوجات متعددة الخامــات

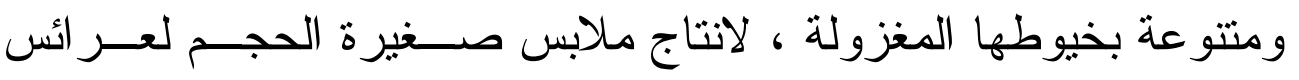
الدمي بتعدد شخصياتها التي تظهر في شكل العر ائس • r-يمكن إيجاد العلاقة التزابطية بين التعبيرات الفنية للاطفال بالاثــغال

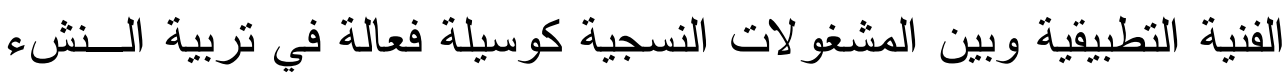
جماليا وفنيا حيث يمكن تتمية التذوق لفن تلك المشغولات لدى الاطفــال من خلال تطبيق بعض الصور و المؤثرات اللونية للخامات المختلفة فــي تعاثقات وتز اكيب نسجية مبسطة وفي مساحات هندسية مختلفة وبتصميم

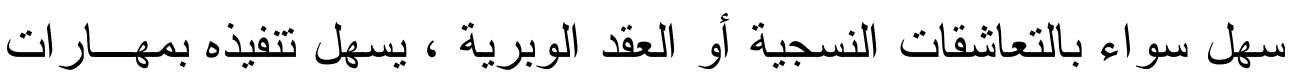
يدوية .

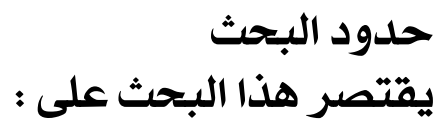

1-الاساليب الفنية لصناعة المشغولات النـسجية بالخامــات و الالــــوان 
و المو اصفات الطبيعية لها و التي تظهر بتتــوع الخيــوط الطبيعيــة و الصناعية بنمر ها المختلفة . ماصن

r-الاساليب التطبيقية في انتاج منـسوجات ملابـس لعــر ائس الــدمي بشخصياتها المختلفة r-الاساليب التطبيقية لإنتاج نسجيات مصورة وبها تصميمات بمساحات هندسية متعددة وتنتخدم كمعلقات أو بتطبيق عقـدة (( جـوردس))

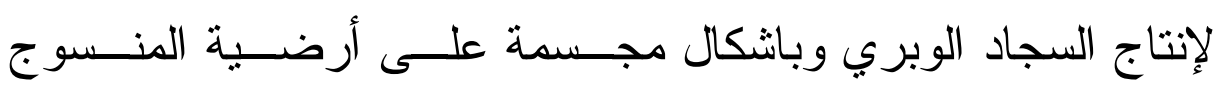

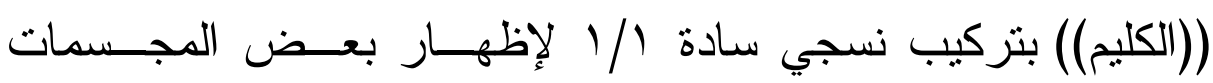
لأشكال نباتية أو آدمية أو حيو انية . لئري

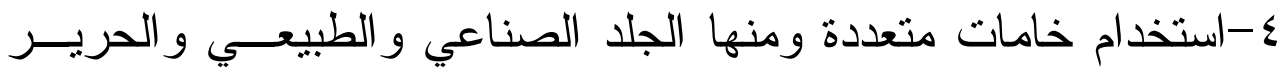

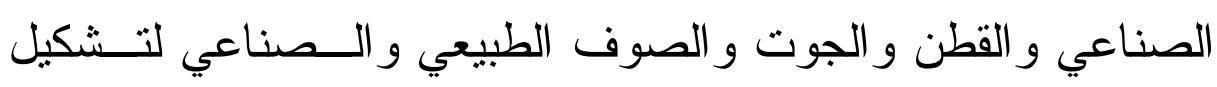
المنسوجات المجسمة و التركيب النسجية

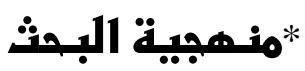

يتبع الباحث المنهج التحليلي في رصد وتتاول الصياغات التشكيلية مــن خلال الخامات و إمكانياتها وتقنياتها المتعددة ، كما يتبع الباحــث المــنهج التجريبي لموضوع البحث في مجال التثريس لأقـسام التربيــة الفنيــة

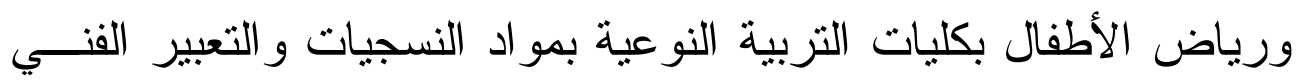
وفنون الأطفال و البالغين و المهار ات الفنية و التدريب الميداني في التزبيـــة

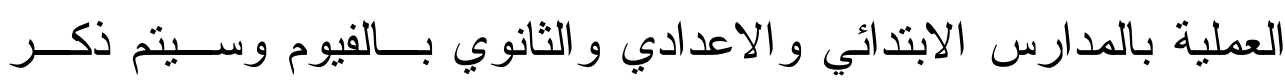

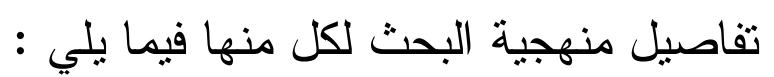




\section{أولا : التنعبير الفنبي المجسسم :}

التعبير الفني المجسم طالما اتسم بجودة التعبير و الاستقر ار و الأصالة التي تمنل أهم القيم المميزة للتعبير الفني السليم ، وهذا التعريف لهذا النوع من التعبير الفني من حيث خاماته ومن حيث بنائه ومن حيث تعبيره ، ومــن حيث العو امل الذاتية ، فهو تعريف شامل أكد على جو انب هامة عديدة ، اهمها اننا يمكن أن نحصل على شكل مجسم باستخدام خامسـات نـسجية

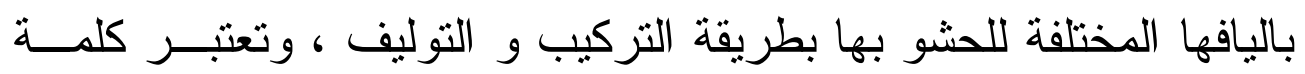

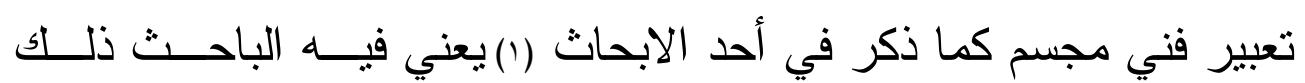

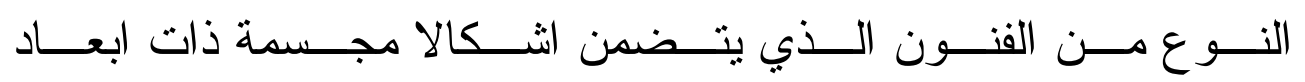

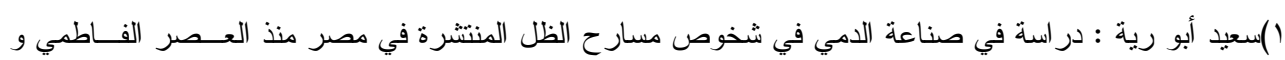

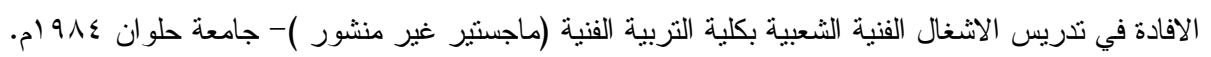


ثلاثية ، حيث الاحساس بالكلمة ، و الحركة و المتعة الفنية ليس من خــلال

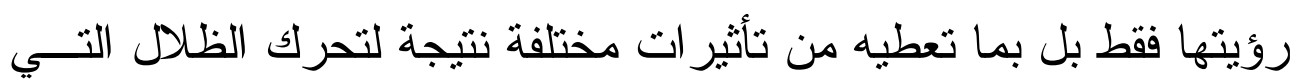
تتشأ من تغيير الضوء الساقط عليها .

وتزجع أهمية در اسة التعبير الفني المجسم للاطفال من الناحية النفسية أن مؤثر ات قطعة العمل الفني المجسم لا شك أن لها أهمية كبرى في مر احل العمر الزمنية المختلفة لممارس ومتذوق هذا العمل وخاصة ما يتـضمنه

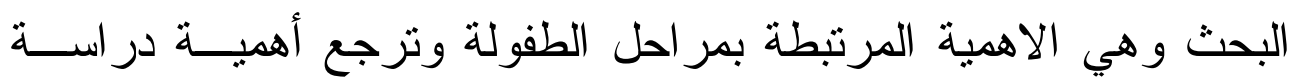
التعبير الفني المجسم للاطفال الى انه أحد الوسائل التي تساعد الطفل في عملية التو افق بين وظيفة الابصار وحركات الاصسابع ، كما تساعده على

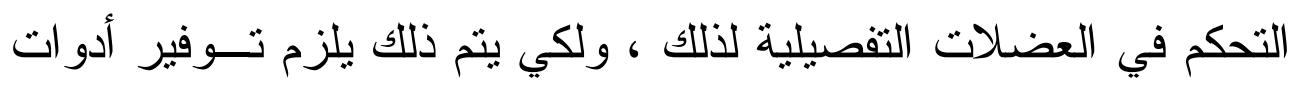

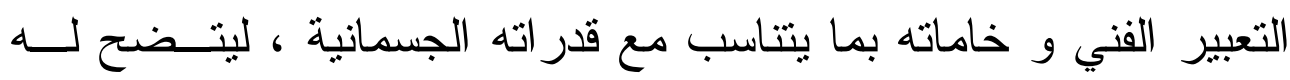

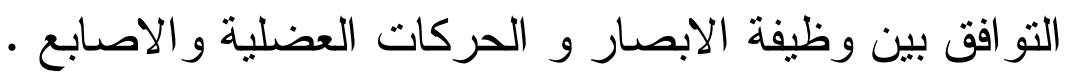
ويميل الطفل في الفترة من 0-9 سنوات الى تصنيف النـشاط اليــدوي و أخص بالذكر النسيج على نطاق واسع وأنــو اع التز اكيــب و الخامــات المختلفة لإشتباع الدو افع النفسية في هذه الفترة .

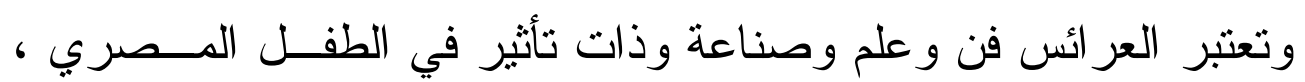

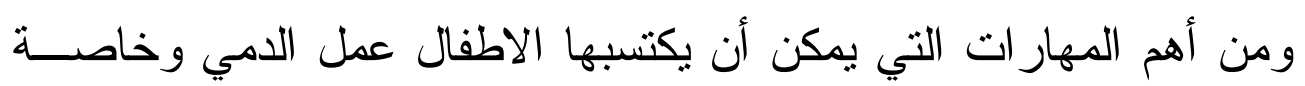

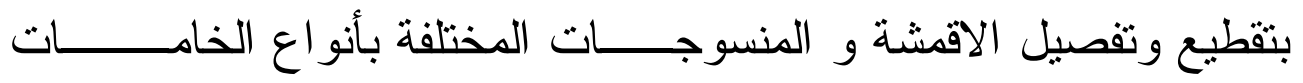


و الألو ان ، لذلك تحرص البرامج التربوية علــى ان يــصنع الاطفــال

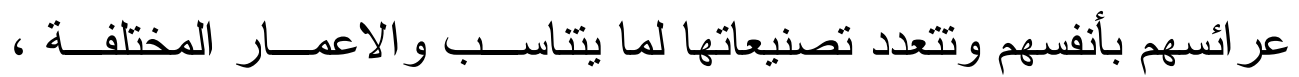
وبالتالي تصبح لكل مرحلة وكل عمر عر ائس خاصة ذات تفاصيل معينة

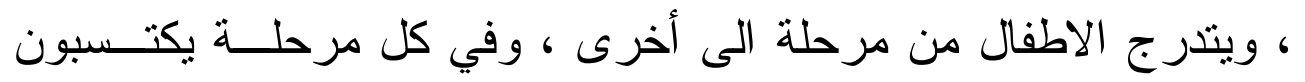

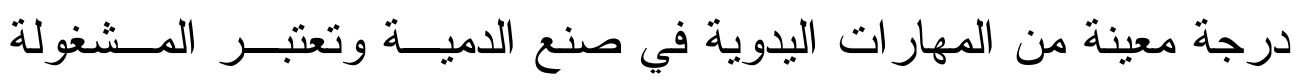

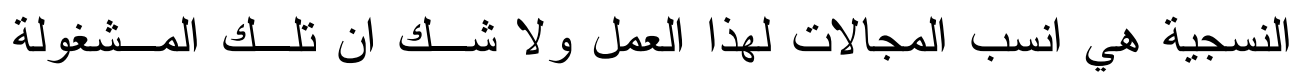

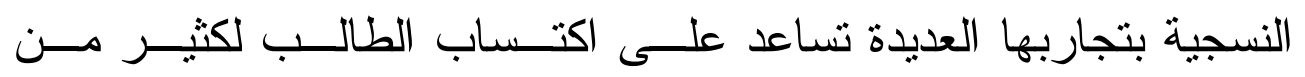
الاتجاهات التربوية كالتعاون و الطاعة وتقبل النقد و الشعور بالمسئولية .

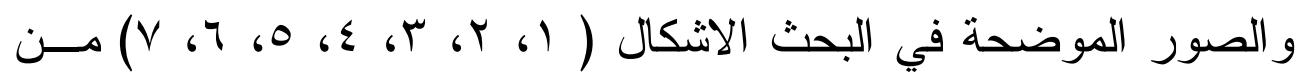
إعداد طلاب المدرسة الإعدادية وهي : رقم (1)عروستان مـصنوعتان

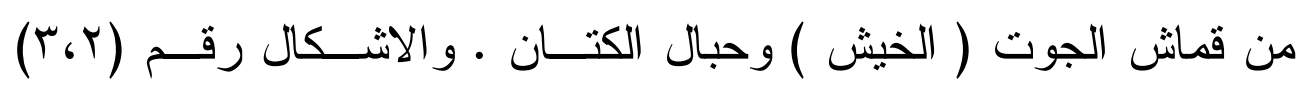

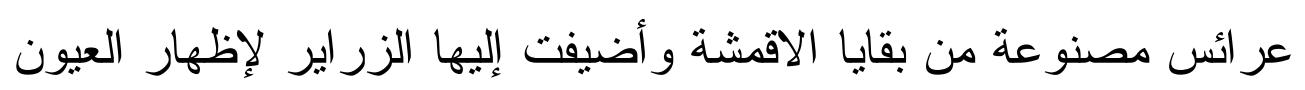

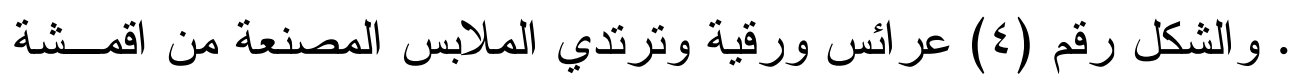
المنسوجات وبها بعض إضافات من الخيوط وقطع معدنية لنخصيات من البيئة المصرية ، ونلاحظ أن تصميم العروسة وضع على أساس الجـسم فئس المخروطي و الر أس عبارة عن شكل كروي ـ و الثكل رقم (0) اســتخدام السلك وخيوط الصوف المغزولة و الملونة في صنع عروسة من النــوع الـــي يعلق عادة في السيار ات و الثكل يبين التوليف الناجح بين خامتين • 
و الثكل (7) نسيج من القماش استخدمت فيه الخيوط القطنية و الــصوفية وجاءت النتيجة منميزة بملادس السطوح وبالتكوين المتميز الذي يجمــع

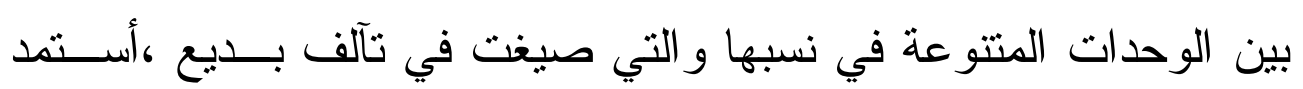
الموضوع من الإيحاءات الثعبية .

في الثكلين (V، ^) استخدمت قصاصات الاقمشة و الخيوط في التعبيــر

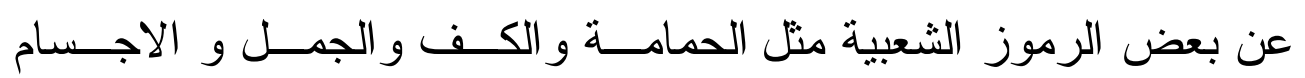
و الوجوه و التصميم ويغلب عليه التمانل . بلن

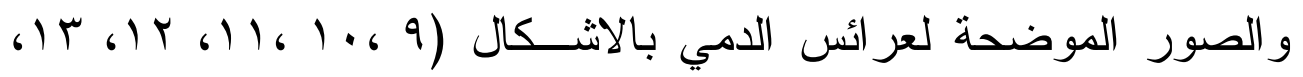

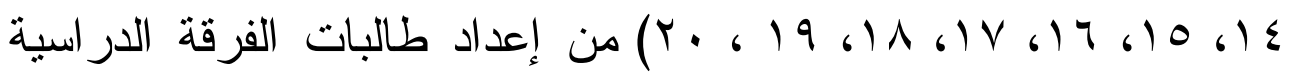
الاولى بقسم رياض الاطفال بكلية التزبية النوعية بــالفيوم ،مــن خــله التدريب الميداني في المدارس وتتعدد شخصياتها فيما يلي :-

ـالاشكال (9 ، ـ (، 1) (1) فتاه صغيرة منهم الريفية و المدنيــة وتتوعــــ

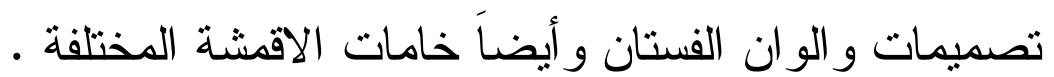

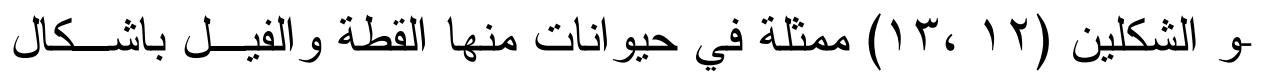
كاريكاتيرية . 
و الاشكال (ع 1 ، 10، 7 1) بشخصيات شيخ البلد بردائه القططان ، و ابن

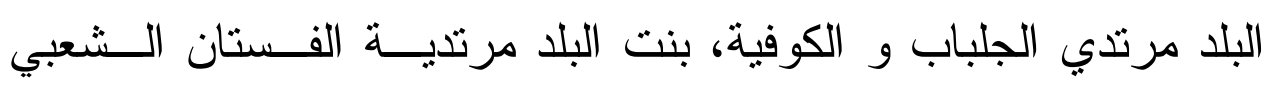

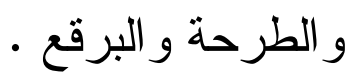

- و الثكل رقم (V l) الفلاح المصري يرتدي الجلباب و الصديري .

- و الاثكال (11 19 19 ) لشخصية الار اجوز و البلياتثو بالملابس و أدوات

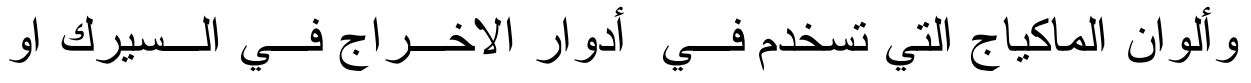
• (المسر حوح

ثانيا : هدف الاشغال الفنية و علاقاتها بالنسجيات ( الشغولات النسجية ) :

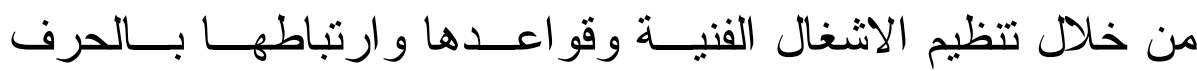

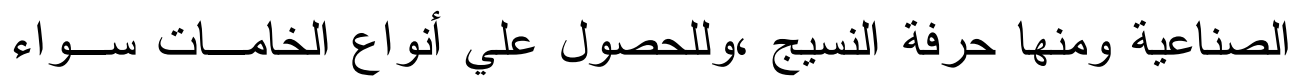

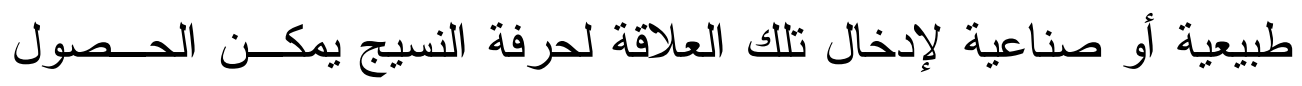
على المميزات الاتية : الماته

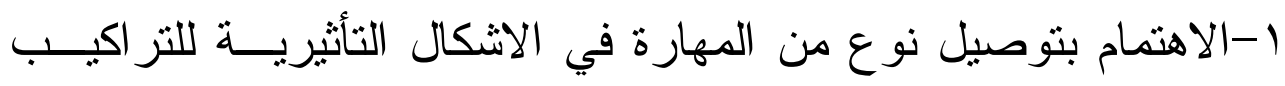

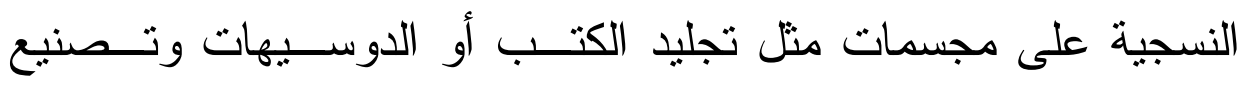
الاكياس و المحافظ و الحقائب الجلدية و عليها التز اكيب النسجية السادة

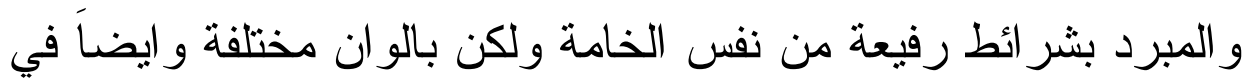

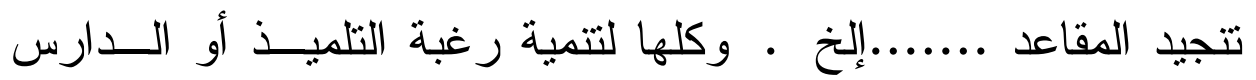




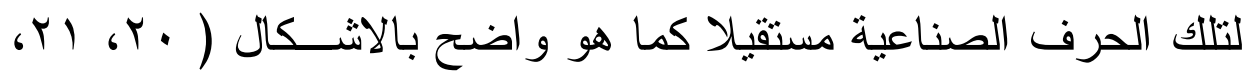
. (ro r r r-بيساعد ذلك على تأكيد الصلة بين اليد و العقل وبين الحركة و التفكيـر بطريقة علمية محسوسة . r-ولتحقيق هدف البحث في هذا الاطار أهمية لمسايرة التربية الحديثــة

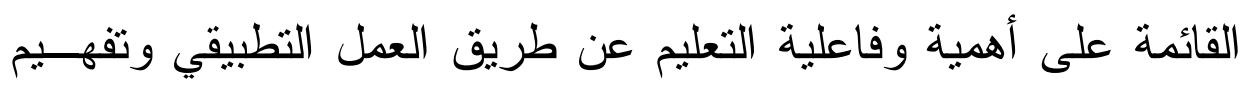

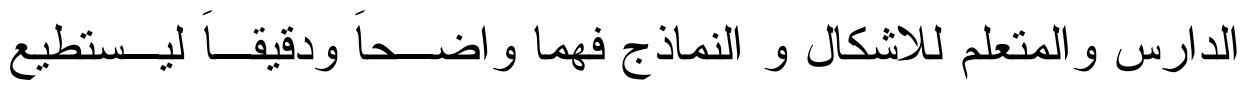
التعبير عنها و إبر ازها مطابقة للمطلوب و الملائمة للاستخدام ، ويـتـت بذللك ابتكار شكل جديد يحقق الغرض المطلوب مـن خــلال الخيــال

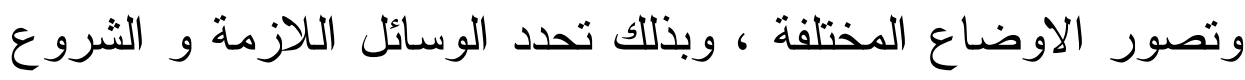
في التتفيذ العملي سو اء كان بالجلد او بالصوف الطبيعي و الــصناعي

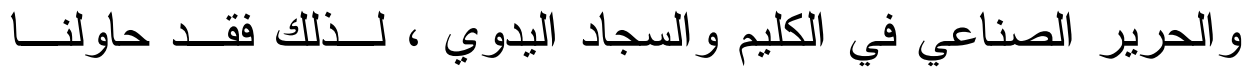

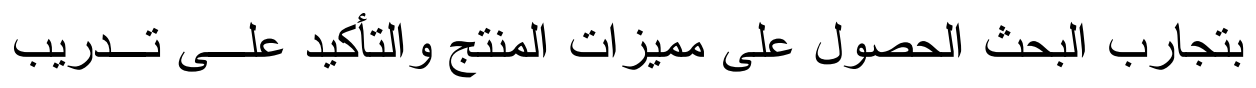

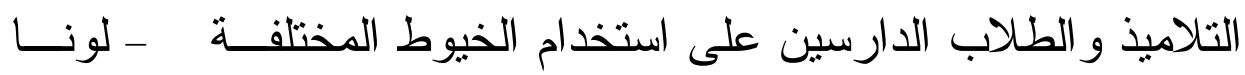

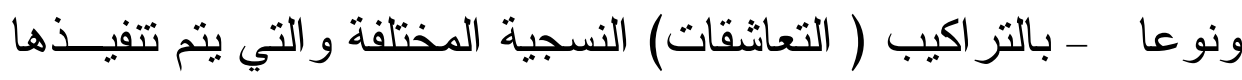
علي الانو ال البسيطة ، و الاسس التي تقوم عليها هذه الفنون وتعريفهر

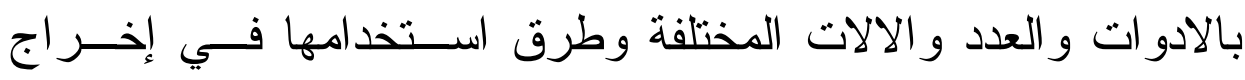

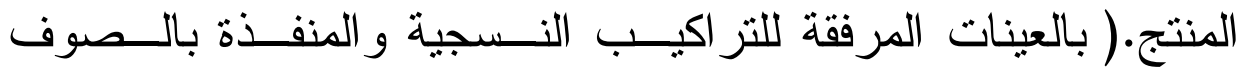
الصناعي ( الخيوط التي تستخدم في انتاج التريكو ). 
ع -القيام بنزويد التلاميذ و الطلاب الدارسين بخبر ات تقدمية جديدة تتــي قدرتهم الابتكارية ، عن طريق الكثف عن زوايا جديدة فيما يحيط بهم

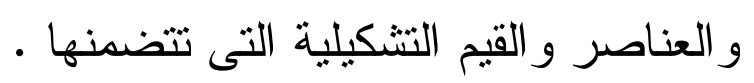

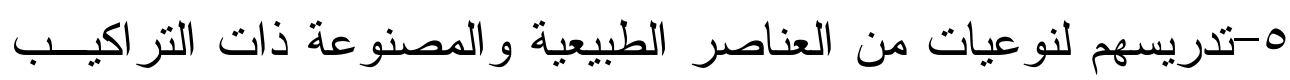
المتعددة لتساعدهم على رفع مستوى التكوين الفني في مجالات التعبير

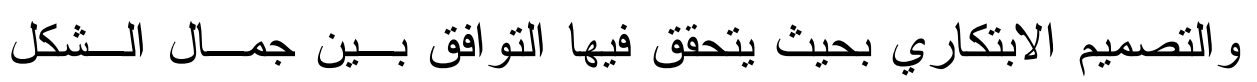

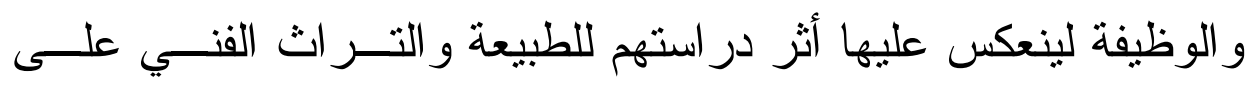

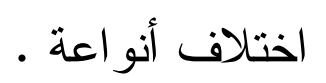

צ-تدريب الطلاب الدارسين في تعبير هم الفني بخامات متعددة في تصميم

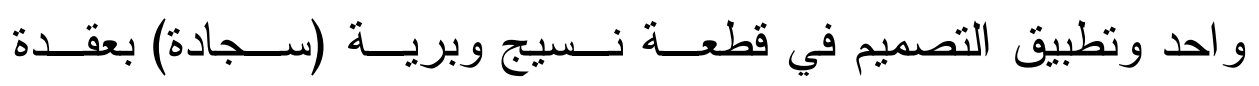
((جوردس)) وقد تم استخدام خامــة الحريــر الــصناعي والــصوف

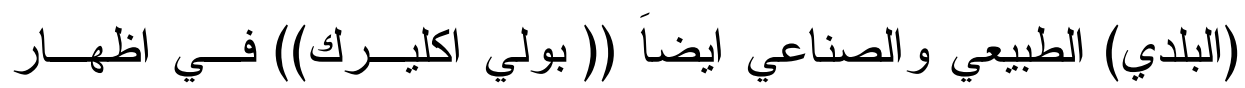
الورقة ببروز ها على نسيج الارضية (كليم ) بالتركيب النسجي سـادة

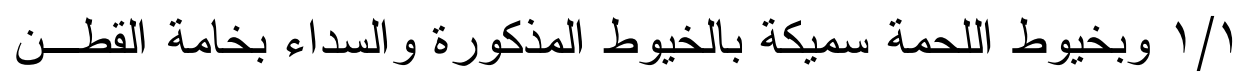

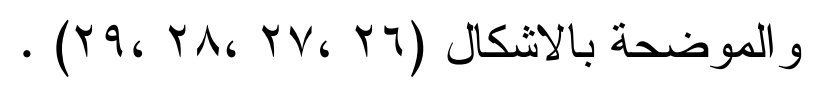
V-تعليم الطلاب الدارسين خلال تعبير هم الفني كيفية اســتخدام الالــــوان الاساسية و الثانوية بدرجاتها المختلفة وذلك بالخامات المتعددة المذكورة كما هو و اضـح بالاتكال المصورة ويتم التمييز بين درجات الالــــوان

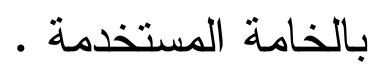


ᄉ-وبتلك التجارب يتم تهيئة الفرصة للتلاميذ و الطلاب الدارسين لإدخال مقتبسات بما يرونه في صياغات تتكيلية فيها انطباعاتهم ودر استهم الفنية

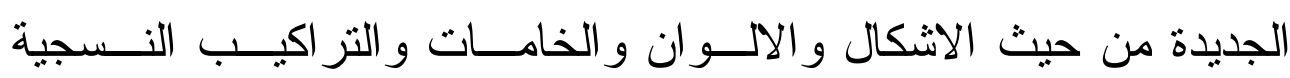

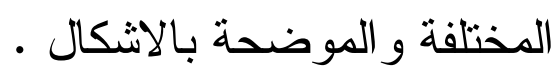
9-تدريب الطلاب على استخر اج بعـض التكوينــات الهندســية الفنــــة لمساحات او لمجموعات من العناصر الطبيعية و إبرازها بالملمس الوبري بلي ( السجادة) او السطحي ( الكليم) بشكل غائر وبارز و الموضحة بالاشكال السابقة ويتم ذلك بوضع تلك التصميمات على ورق المربعات التي تخص الرسم التنفيذي و التـي ينت تتفيذها على انوال السجاد العادية لامكانية الــتحكم فـــي الزخـــارف

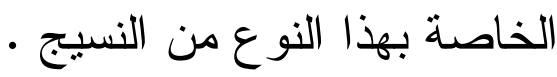

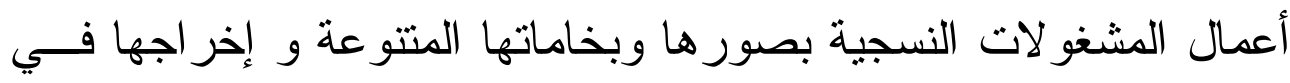

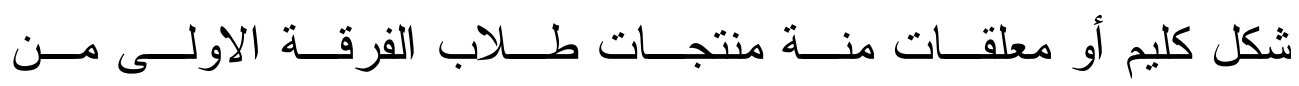

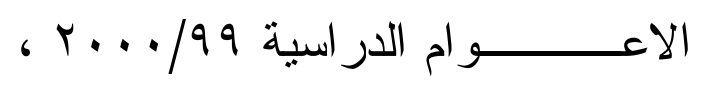

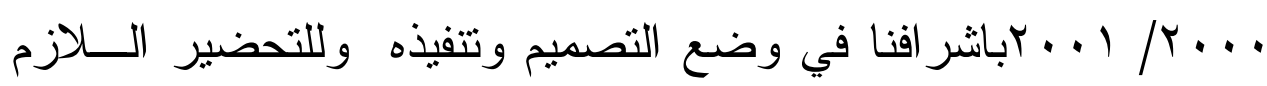
للتدريب الميداني بالمدارس • و ايضـا أعمال الكليم و السجاد اليدوي من منتجات طلاب الفرقة الدر اســية

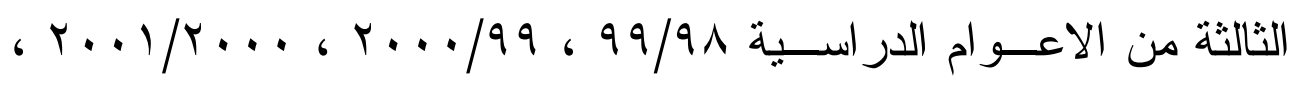

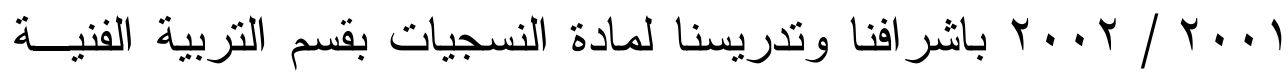


بكلية التزبية النوعية بالفيوم •

\section{فلاصة نـنائج البـهن}

نستطيع ان نلخص الوسائل التي تساعد على تحقيق هدف البحــث مــن التجارب التي تم إعدادها وبدر اسة نتائجها التي أثنتت إمكانية تتمية الذوق الجمالي و المهار ات الابداعية عند الطفل في النقاط الاتية : 1- إلغاء الامية للطفل وتعويده على الرؤيـــة الواضــــة و الــصحيحة و الو اعية و الاهتمام برؤية التفاصيل و عدم الاكتفـــاء بالرؤيــة الــسطحية للاشياء . r-إعطاء الحرية للاطفال في التعبير مع التوجيه في أضيق الحدود و عند الضرورة وخاصة الاطفال حتى سن 10 سنة . r- الحث على البحث و التجريب كمدخل اساسي لعملية الابتكار و الابداع - الفني ع - توفير الخامات المناسبة لعمل التلاميذ و الطلاب بحريـــة و ألا تكـــون الخامات و الادوات الفنية المقدمة للتلميذ او الطالب سببا في إعاقته عـن العمل ومنحة الفرصه كاملة للبحث في الخامسـات وتجريبهــا وخاصـــة الملونة بالصبغات او بلونها الطبيعي • 0- إعطاء التلميذ او الطالب فرصة للتشكيل المجسم خلال فتر ات نمــوه الفني حتى يصل الى نهاية مرحلة الطفولة وقد تعرف على الفــرق بـين 
الانشكال المسطحة و الاشكال المجسمة وكذلك إعطائه الفرصــة للتعــرف على الملامس المختلفة. 1-التعرف على الالوان ومكوناتها ودورها في الاعمال الفنبــة وكــذلك الالو ان الطبيعية للخامات المختلفة . - التذرب على الاعمال الجماعية و التأكيد على أهميــة التكامــل بــين

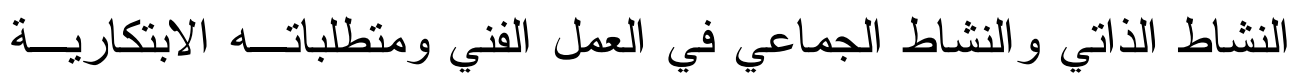
و التنفيذية . 1- إعطاء الطفل فرصة لمشاهدة الاعمال الفنية التي تتشـابه مع اســلوب تعبير الاطفال ورؤية المعارض الفنية . 9- مساعدة الطفل على تتمية التذوق الجمالي ومعرفة دور الجمال ودور

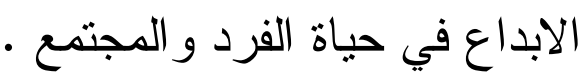
• 1- تذوق التز اث المحلي ومعرفة فنون الآباء و الاجداد وخاصة الفنـــون الثعبية و الحرف المهنية مما يزيد من التصاق الطفل ببيئنه المحلية . 1 1- اكتشاف المو اهب الفنية المبكرة لدى الاطفال و العمل علــى تــوفير سبل الرعاية لها للوصول بها الى المستوى المطلوب ، لأن تشجيع الطفل المو هوب و استحسان أعماله يشجع باقي الاطفال على الابتكار و الابداع •

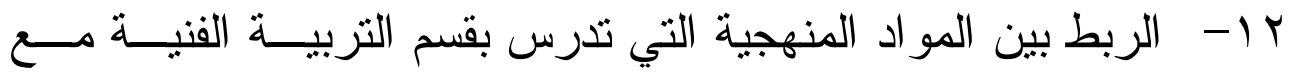

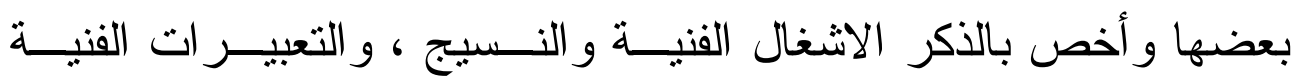
و المهار ات الفنية . 
يوصى الباحث بتتبع التلاميذ أو الطلاب الموهـــبين خــلال مــر احلهم

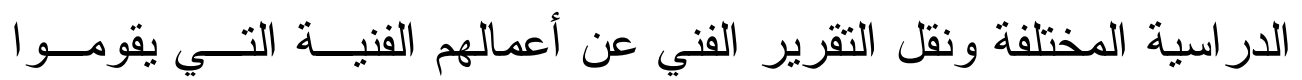
بإنتاجها للمعلمين في مر احل در استه سو اء بالمدرسة أو بالكلية ليـستطيع

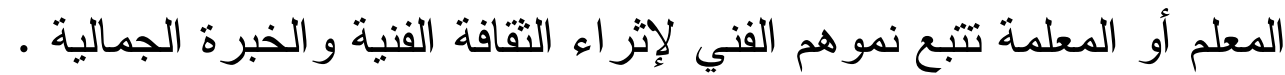

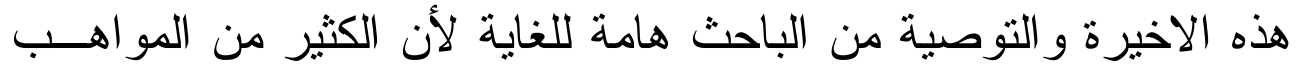
يقضى عليها وهي في مهدها لأنها لم تجد الرعاية و الاهتمام الكــافيين ، ومعلم الفن معذور في هذا العدد الهائل من الاطفال و التلاميذ و الطلاب ، ومثل هذا التقرير عن الطفل أو التلميذ سيساعده في استكمال مـــا بــــأه الزميل معلم الفن في المرحلة السابقة مع الطفل وسنصل في النهاية الــى الطفل الفنان المبدع ، وبالتالي نحصل على عــد كبيــر مــن الفنــانين المبتكرين و المبدعين لأن طفل اليوم هو فنان الغد. 


\section{المراجـع}

1- تحية كامل حسين : مسرح العر ائس و الألف كتاب ، دار الكرنـــــ ،

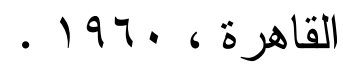

r- سعد الخادم : الدمي المتحركة عند العرب ، الدار القومية للطباعــة و النشر ، ص 1 ، 9 بدون تاريخ نشر .

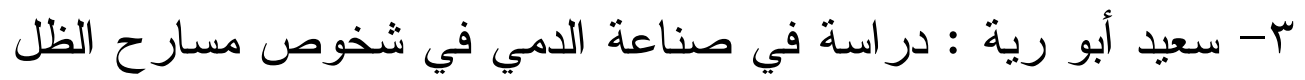

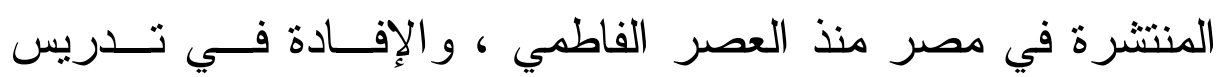

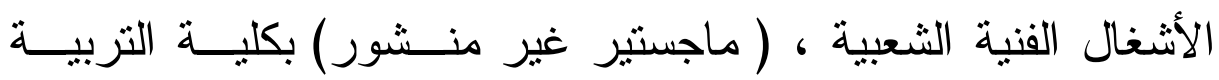

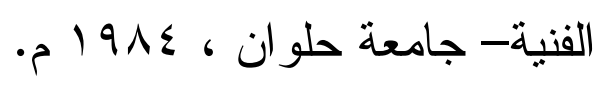

ع - سليمان محمود حسن : المعلقة في الفن التشكيلي ، مجلـــة دراســات

$$
\text { وبحوث ، جامعة حلوان مارس } 191 V \text { م. }
$$

0- سليمان محمود حسن : السلالة العظيمة من العر ائس الـشعبية فـي ماني

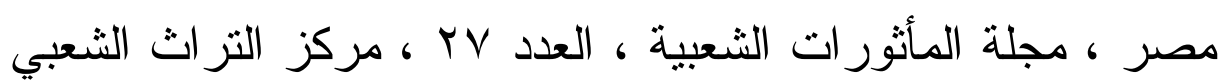
لمجلس التعاون الخليجي ، الدوحة ، ب99 199 م.

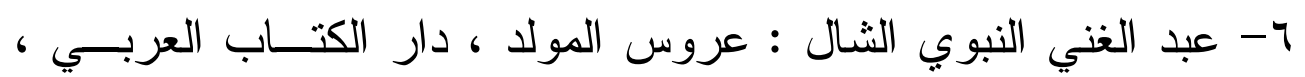

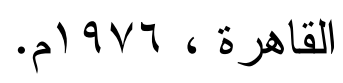

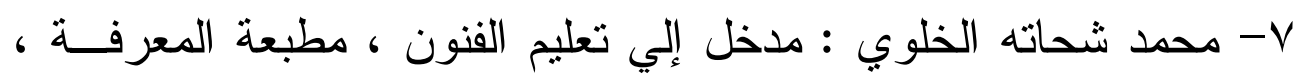


ي : الحــث الجمــالي ، دار المعــارف

$$
\text { 1- محمــد صــديق الجبــاخنجي }
$$

9- محمود البسيوني : طرق تعليم الفنون ، دار المعــارف ، القــاهرة ،

$$
\text { س } 197
$$

• - مختار السويفي : خيال الظل و العر ائس في العالم ، دار الكتاب

$$
\text { العربي للطباعة و النشر القاهرة لو } 97 \text { ام. }
$$

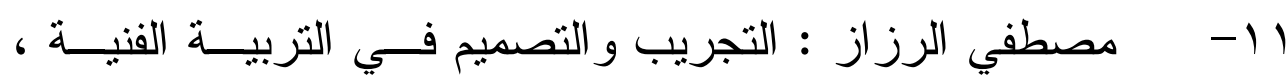

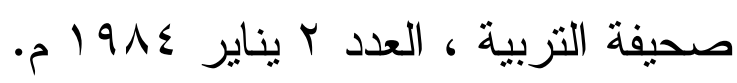

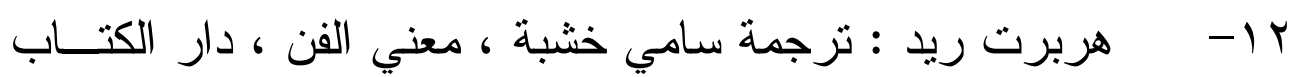

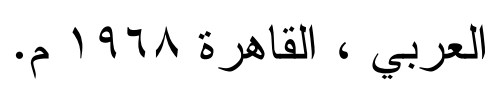




\section{ملخص البحث}

يرذف البحث إلي محاولة تطبيق عمل تتفيذي تجريبي بالطابع الفني لتغذية الأطفال بالإعداد العلمي و الفني التطبيقي لتنمية مهار اتهم و إخــر اج إنتاج مبنكر بمستويات مختلفة من المشخو لات النسجية و التي تشمل : - الإعداد العلمي لتتمية مستوي الوعي و الإدر الك المعرفي للطفل . - الإعداد العلمي لتتمية مستوي الحركة و المهارة اليدوية للطفل وترجع أهمية البحث للمساهمة في الارتقاء بتربية الطفولــة فــي البئـــة المصرية و لإمكانية تحديد مسيرة العملية التربوية ونتائجها فـــي مجــال التربية القنية من خلال الأهداف الآتية : ا- مساعدة الأطفال علي العناية بمستو اهم العلمي و الفني • r- ممارستهم المهار ات البدوية و الفنية لإخر اج المنتجات المبنكرة .

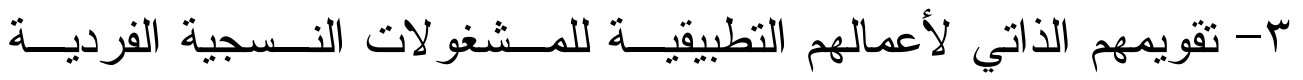
و الجماعية للكثف عن أخطائهم و الإفادة منها في أعمــالهم المقبلــة وتميز المنتجات الجيدة في أدائها الموضحة لتعبير اتهم الفنية . ع - أهمية التطبيقات التزبوية إذ تتمي قوة إدر الك الأطفال لنوعية الخامات التي تستخدم في الإنتاج و التي تشمل الخـــو اص الطبيعبــة كــاللون و الملمس و المرونة و أنو اعها الطبيعية و الــصناعية و الأدوات و الآلات 
التي تستعمل في تشغيلها في الأنشطة التخطيطية المنتظمة .

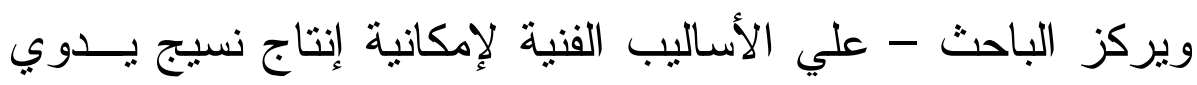

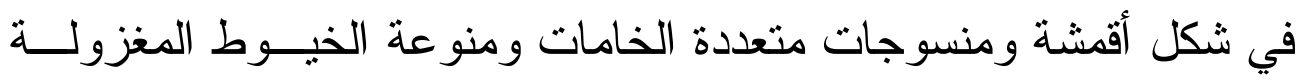

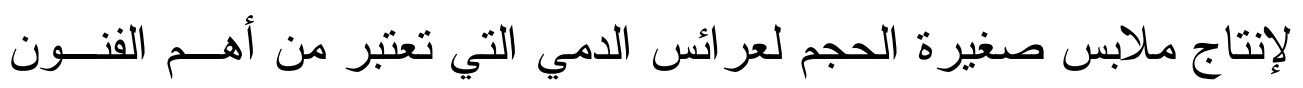

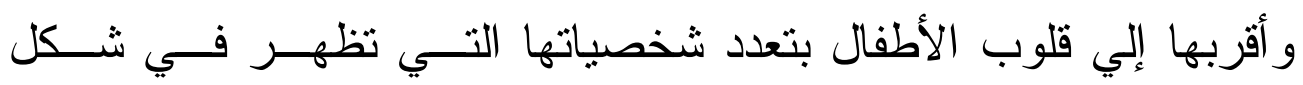

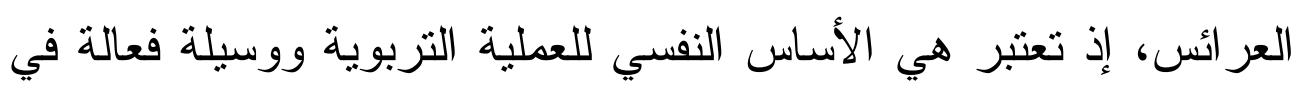
تربية النشئ • كما يركز الباحث أيضاً علي إمكانية إيجاد العلاقة التز ابطيــة بــين

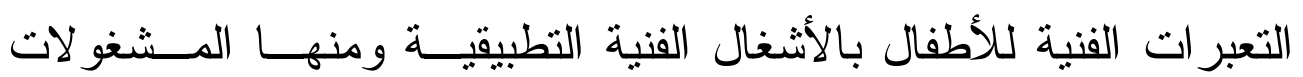
النسجية حيث يمكن تتمية التذوق لفن تللك المشغو لات لدي الأطفال مــن خلال تطبيق بعض الصور و المؤثز ات اللونية للخامــات المختلفــة فـي التز اكيب و التعانقات النسجية المبسطة وفي مساحات هندسـية مختلفــة وبتصميمات مبتكرة وسهلة " نسجية" و " وبرية" ويسهل تتفيذها بمهار ات إدر اكية .

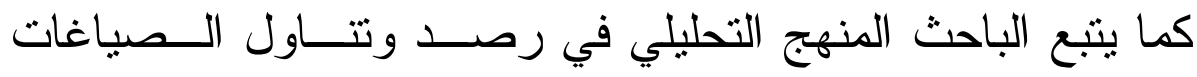

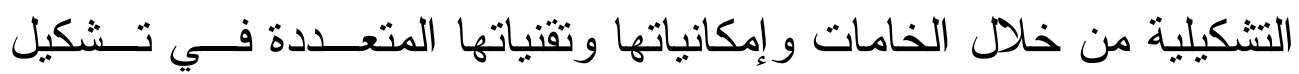

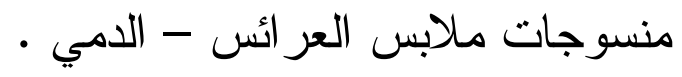

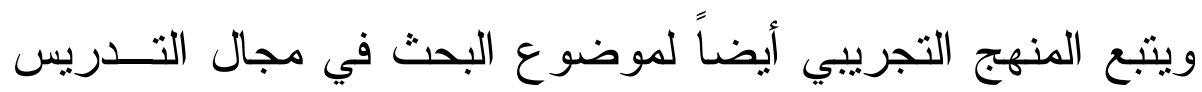

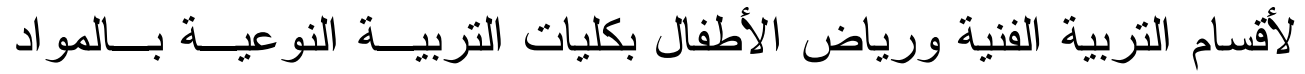


الموضوعة في مناهج التنريس وهي النسجيات و التعبير الفني و المهار ات

الفنية للطفل و أيضاً فنون الأطفال و البالغين وتطبيقها أيضًاً فــــــــــال التدريب الميداني بالمدارس الابتدائية و الإعدادية و الثانوية . وقد شمل البحث التعبير الفني المجسم و المشغو لات النسجية لــربط العلاقة بين مادتي الأشغال الفنية ومادة النسجيات في قسم التزبية الفنية ، و إعداد المعلم الذي يتولي تعليم الطفل بإعداده للتخطيط التربوي و الفنـي و التطبيقي لكسب العمليات العقلية و الفكرية و التعبيرية الناتجة من الأطفال

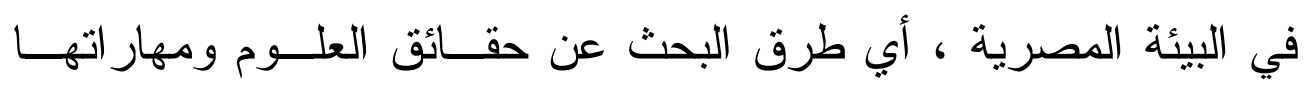

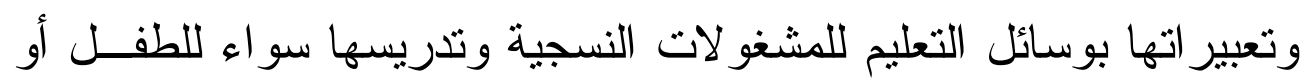
معلم الطفل لإمكانية نوصيل المعلومات المختلفة إلي ذهن الطفـلـل لتتــــو وتتزي مادته وقدرته للتطبيق العملي بالمهار ات اليدوية اللازمة . كما يوصي الباحث بضرورة تتبع التلاميذ و الطــلاب الموهـــــين خلال مر احلهم الدر اسية المختلفة ونقل التقرير الفني عن أعمالهم الفنيـــة

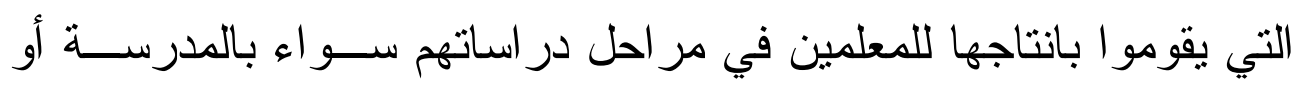

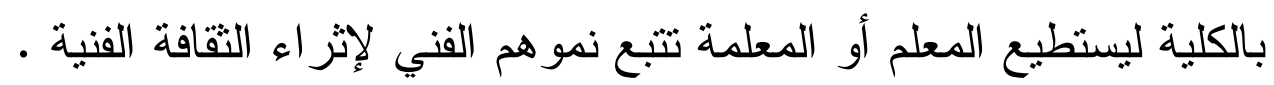




\section{ملحــق}

عينات من المنسوجات اليدوية إنتاج تلاميــــ المر احــل الدراسـية

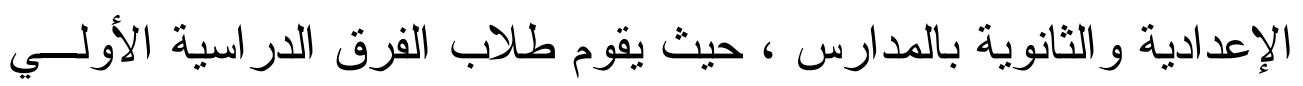

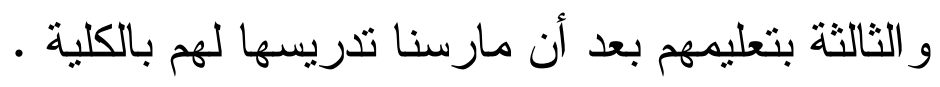

وتتمل التز اكيب النسجية :

السادة ومشتقاته و المبرد ومشتقاته و النسيج الــوبرى بعقــدة ســـينا

وعقدة جوردس بإستخدام خامة الصوف الصناعي و علي الأنو ال البسيطة

(الكرنون، الخشبية) كما تثمل أيضاً تأثير الألوان وسمك الخيوط ومهـدي

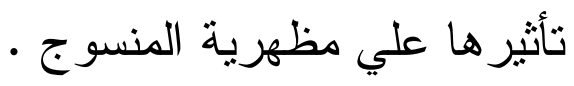

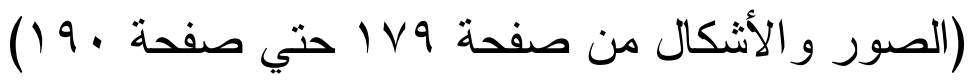


- 179 . 
- 180 - 
- 181 . 
- 182 - 
- 183 - 
- 184 - 
- 185 - 
- 186 - 
- 187 - 
- 188 . 
- 189 - 


\section{Summary}

This research is meant to create textile designs using ornamental elements and units of Islamic Art to be used as souvenirs. Analytical-descriptive methodology is used in terms of the theoretical frame. It includes:

1-Classify and analyze the Islamic ornaments.

2-Abstract the aesthetic and artistic values to be used in designing the souvenirs.

\section{Moreover, the experimental methodology is applied. It contains:}

1-Research sample : Students from the first and third year in the Artistic Education Department have been haphazardly selected.

2- Research Material : Students experience that includes studying two units of eight lessons.

3-Materials of cotton, natural wool and artificial wool and silk have been used. Also, plain textile formations $1 / 1$ as well as hairy cloth with Gordes knot have been applied.

4-Final preparation of the cloth formation to be used as a 
souvenir.

5-show the products to the Arbitration Committee that includes experts in this kind of art. They evaluate the products using the evaluation card designed by the researcher.

The importance of this research is attributed to the discussion of how to improve the taste of the Islamic Art especially when producing cloth items with Islamic elements and units to be used as souvenirs which attract tourists and help in developing tourism. Moreover, this subject is considered as a rich field in which different cloth designs could be taught and implemented in order to create innovative designs that could be used as souvenirs. This, in fact, develops the creativity skills of the students in the Faculty of Specific Education.

The researcher recommends that ornamental units and Islamic elements should be used in a modern way to produce aesthetic designs that ere easy to be applied and used as souvenirs. Another recommendation is that tourist governorates should encourage the development of souvenirs production in a way that reflects the cultural and social values of each governorate. Futhermore, the researcher recommends that a supervisory committee should be formed to monitor the production of souvenirs to improve the quality. This association should provide cheep materials so that the souvenir can be of good quality and reasonable price. 